\title{
Screening of medicinal plants used by the Garifuna of Eastern Nicaragua for bioactive compounds
}

\author{
Felix G. Coe*, Gregory J. Anderson \\ Department of Ecology and Evolutionary Biology, University of Connecticut, Storrs, CT 06269-3043, USA
}

Received ; revised 2 April 1996; accepted 6 April 1996

\begin{abstract}
As part of a larger study of the plants used by the Garifuna of eastern Nicaragua, the 229 species representing 177 genera and 72 families used for medicinal purposes were assayed for the presence of bioactive compounds. A review of the literature for alkaloids and glycosides showed that 113 species contained at least one of these bioactive compounds. The remaining 116 species not previously cited were tested for alkaloids with Dragendorff's reagent; 51 contained alkaloids. The combined results show that $72 \%$ of the species the Garifuna use medicinally have at least one alkaloid or glycoside. Tests to explore pharmacological activity of compounds from selected species represent the next step to determining efficacy and application of these medicinals.
\end{abstract}

Keywords: Alkaloids; Glycosides; Garífuna; Medicinals; Ethnomedicine; Eastern Nicaragua

\section{Introduction}

Medicinal plants are the oldest source of pharmacologically active compounds and provided virtually the only source of medicinally useful compounds for centuries (Cordell, 1981). Today it is estimated that more than two-thirds of the world's population relies on plant-derived drugs; some 7000 medicinal compounds used in the Western pharmacopoeia are derived from plants (Caufield, 1991). In the USA, approximately 25\% of all prescription drugs used contain one or more bioactive compounds derived from vascular plants

\footnotetext{
* Corresponding author.
}

(Farnsworth and Morris, 1976; Farnsworth, 1984a).

Few new drugs are being developed from wild sources such as tropical forests because of the high cost and the rigid requirements for their development (Tyler et al., 1988; Principe, 1992). However, no matter how high the dollar cost may be, the loss of the potential for discovery of new treatments for serious human ailments is even greater. The annual rate of tropical deforestation is estimated at 8-11 million hectares (Myers, 1984, 1985). Predictions are that by the year 2050 as many as $25 \%$ of tropical plant species will be extinct (Lucas, 1978; IUCN, 1986; Caufield, 1991; Raven, 1988). The destruction of tropical rainforests in eastern 
Nicaragua, as elsewhere in the world, is rampant. By the year 2000, Nicaragua may have lost more than $50 \%$ of its 1981 rainforest (Caufield, 1991). With this loss goes the opportunity for discovery of new drug plants. The loss of habitat and the extinction of species in tropical forests is disturbingly rapid, but ethnobotanical information is being lost at an even faster rate. With the diminution, dilution or decimation of traditional plant-use practices goes the opportunity to apply knowledge accumulated during hundreds of generations of human empirical testing of bioactive compounds.

Many pharmaceuticals we use today are of botanical origin and are based on herbal remedies from the folk medicine of native peoples (Tyler et al., 1988). Schultes (1986) suggests that the most important drugs of the past 50 years or so were first isolated from plants used ethnomedically. In fact, $74 \%$ of the 119 biologically active plantderived compounds at present used worldwide were discovered as a result of research on species first identified in ethnobotanical surveys (Farnsworth and Soejarto, 1985; Farnsworth, 1988). Thus, phytochemical screening of plant species of ethnopharmacological use will provide valuable baseline information in the search for new pharmaceuticals. Yet fewer than $10 \%$ of tropical plants species have been examined for the presence of bioactive compounds (Myers, 1984).

The pharmacopoeia of the Garifuna of eastern Nicaragua consists of 229 species representing 177 genera and 72 families of vascular plants (Table 1). From these medicinals several hundred remedies are prepared that are used in treating more than 30 human ailments (Coe and Anderson, 1996). The objectives of this study were to survey the literature for alkaloids and glycosides of these 229 species, and to run assays for alkaloids on those not reported. These results are then used to consider the efficacy of these medicinals, and we hope they may lead to more detailed phytochemical and pharmacological analyses.

\section{The people}

The Garifuna are descendants of Red Carib Islanders and African slaves (Davidson, 1976, 1980; Crawford, 1984). They are relative newcomers to the Atlantic Coast of Nicaragua. They arrived in eastern Nicaragua ca. 1890 to work in the extraction of timber (mahogany) around the Pearl Lagoon in eastern Nicaragua (Hale and Gordon, 1987). The Garifuna communities in the Pearl Lagoon area of Nicaragua (Fig. 1) were founded around the turn of the century (Davidson, 1976, 1980), and are the southernmost site of Garifuna culture. At present there are about 1500 Garifuna living on the Atlantic Coast of Nicaragua (Davidson, 1980; Hale and Gordon, 1987). Most of the Garifuna live in four small villages (Justo Point, La Fé, Marshall Point, and Orinoco), all on the southwest rim of the Pearl Lagoon (Fig. 1). One of the authors has observed that the largest of these settlements is Orinoco with a population of 650 , in nearly 100 dwellings (see also Davidson, 1980). The Garifuna practice slashand-burn agriculture on small plantations of 1-2 ha. in size. Their major sources of income are agriculture and logging, with fishing and hunting done seasonally. They participate in the local market economy, selling some of their goods in regional markets.

\section{Study area}

Nicaragua is the largest of the Central American republics. It encompasses about $140000 \mathrm{~km}^{2}$, of which $41700 \mathrm{~km}^{2}$ is tropical forest (Sutton, 1989). The Eastern Lowlands of Nicaragua are the most extensive landform in the country, making up about one third $\left(41000 \mathrm{~km}^{2}\right)$ of the national territory. These lowlands run from sea level to an elevation of $200 \mathrm{~m}$. The eastern lowlands have a tropical climate $\left(25-30^{\circ} \mathrm{C}\right)$, with a rainy season of 6-8 months. Climatic factors combine to yield a rainforest (average annual rainfall: $3810 \mathrm{~mm}$ ), the most extensive in Central America.

Due to the density of the rainforest, abundance of rainfall, and regular distribution of rivers, the east coast of Nicaragua remained essentially undeveloped and isolated from the rest of the country until roads were built recently. The primary means of transportation in the eastern lowlands is still by boat or airplane. The largest city is Bluefields (Fig. 1), in which $60 \%$ of the lowland population lives. The primary forest type 


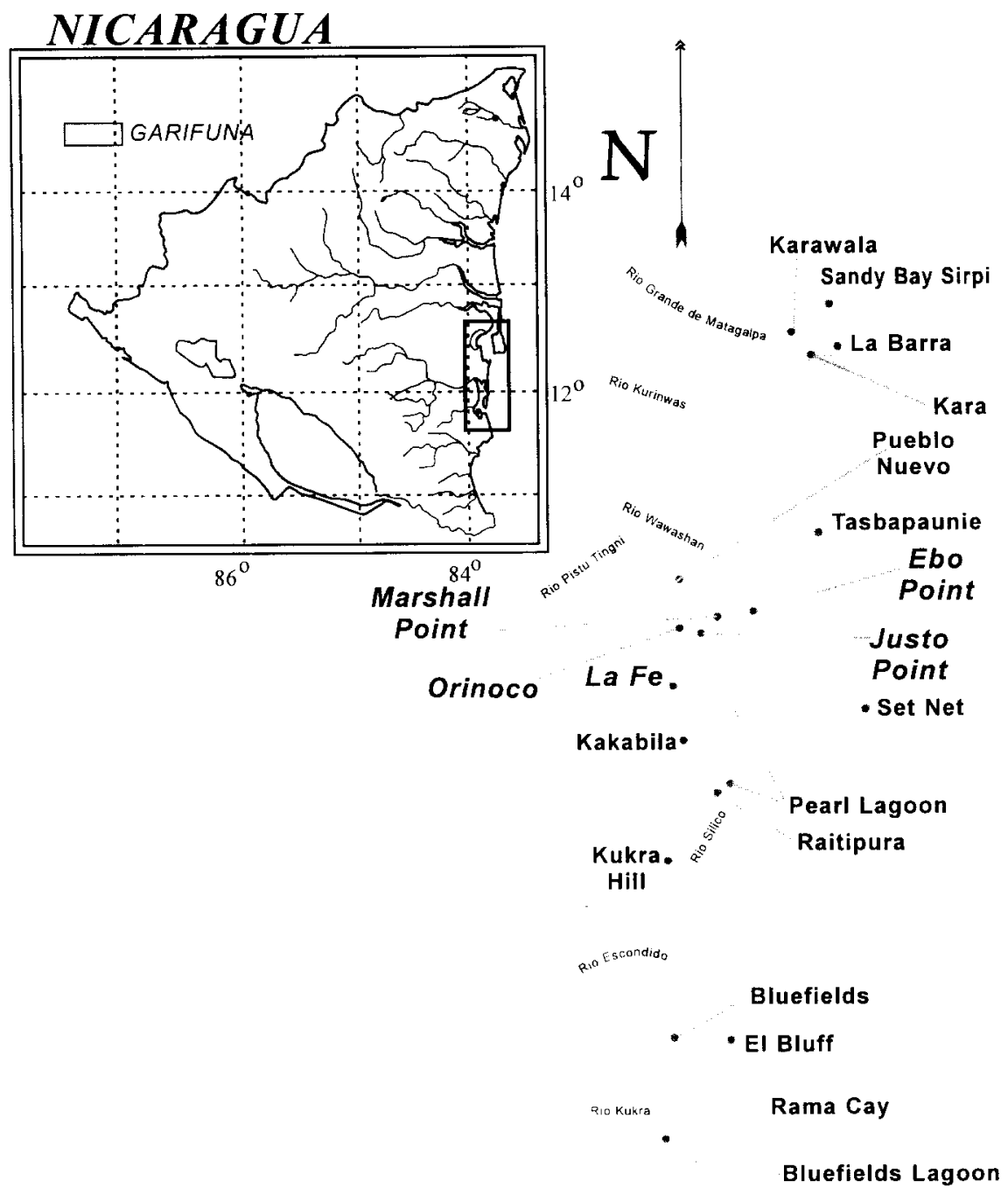

Fig. 1. Present distribution of Garifuna settlements in eastern Nicaragua.

around the Garifuna settlements in the Pearl Lagoon area is lowland swamp forest (Sutton, 1989) characterized by the abundance of mangroves and palms along the shore of the lagoon and river banks.

\section{Materials and methods}

Interviews of practitioners (shamans, midwives, and others) were conducted and plants were col- lected for a period of several months in 1992-1993, around the Pearl Lagoon and other settlements along the Wawashan River of eastern Nicaragua (Fig. 1). Further details about this study and the practitioners are published elsewhere (Coe and Anderson, 1996). Voucher specimens were prepared and deposited at the Herbarium of the Atlantic Coast of Nicaragua in Bluefields (established by Coe in 1992), the Missouri Botanical Garden (MO), and the Univer- 
sity of Connecticut (CONN). The 229 Garifuna medicinals (Table 1) were surveyed for alkaloids and glycosides. This was determined by doing a literature search, covering the period of 1950-1994, of major compendia, including manual and electronic sources on alkaloids (Karrer, 1958, 1977, 1981, 1985; Willaman and Schubert, 1961; Hegnauer, 1962, 1963, 1964, 1966, 1969, 1973, 1986, 1989, 1990, 1992, 1994; Willaman and HuiLin Li, 1970); Chemical Abstracts Services (CAS); and Natural Products Alert (NAPRALERT).

The 116 Garifuna medicinals tested for alkaloids are those species not reported in the literature. Plant parts tested are the same as those used in the preparation of herbal remedies, and included both aerial and underground parts (Table 1). Plant materials were obtained from mature individuals in flower or fruit, and collected and processed according to standard practices (Lawrence, 1951; Bridson and Forman, 1992; Soejarto, 1993; Soejarto et al., 1996). Alkaloid tests were done in the same way in the field and in the laboratory, using Dragendorff's reagent (Harborne, 1988; Stermitz et al., 1989) and thin-layer chromatography (TLC) (Stahl, 1969; Stermitz et al., 1989).

Alkaloids were determined qualitatively by macerating $10-15 \mathrm{mg}$ of plant material in a test tube in 1-2 $\mathrm{ml}$ of $1 \mathrm{M} \mathrm{Na}_{2} \mathrm{CO}_{3}$. Once macerated, 0.5-1.0 ml of 2:1 $\mathrm{CHCl}_{3}-\mathrm{MeOH}$ was added. The mixture was then mixed with a stirring rod for 3-5 $\mathrm{min}$, then allowed to stand and separate into two phases. The lower phase containing the plant extract in $\mathrm{CHCl}_{3}$ was drawn off with a disposable pipet into a depression in a spot plate. The $\mathrm{CHCl}_{3}$ was allowed to evaporate to about a drop $(0.025$ $\mathrm{ml}$ ). This amount was spotted on an aluminumbacked TLC strip $10 \mathrm{~mm} \times 40 \mathrm{~mm}$ in size. The strips were developed in $\mathrm{CHCl}_{3}$ and alkaloids were visualized (color ranges are yellow/orange, red/orange, red/black, pink, and even purple depending on the species or genus) by spraying with Dragendorff's reagent. Alkaloids were considered present in a plant part when at least two of three replicates gave positive results; number of spots on the TLC strip was not recorded. Since field alkaloid tests can sometimes produce falsepositive reactions, especially in latex-bearing families, e.g. Apocynaceae, Asclepiadaceae, and Moraceae (Farnsworth, 1966), test results, as applicable, for the above families were verified with reports in the literature. However, the method (Stermitz et al., 1989) used includes a purification procedure (adding a base $-\mathrm{Na}_{2} \mathrm{CO}_{3}-$ and extraction with a water immiscible organic solvent $-\mathrm{CHCl}_{3}$ ) that helps avoid false-positive reactions. Glycoside tests were not done because of time constraints and the complexity of the testing procedure.

\section{Results and discussion}

More than 250 plant species are important to the Garifuna as sources of food, fiber, construction and craft materials, and medicine (Coe and Anderson, 1996). Medicinal plant species constitute by far the largest use category (Table 1). Among the 229 medicinal species, 113 contain at least one alkaloid or glycoside reported in the literature (Table 2). Of the remaining 116 species, 51 species, representing 45 genera and 25 families, tested positive for alkaloids (Table 2). Thus, 152 species of the Garifuna medicinals contain alkaloids and an additional 12 contain glycosides (Table 2). About one-half (43\%) of alkaloidbearing species are herbs, and about one-third $(28 \%)$ are trees (Table 3).

The Fabaceae had the highest number (20) of species with alkaloids (Table 4). As this would lead one to expect, this family contains many medicinals that are highly regarded by Garifuna healers (Coe and Anderson, 1996). Several other families also have a number of genera and species used medicinally that possess alkaloids (e.g. Euphorbiaceae, Rubiaceae, Solanaceae) (Table 4). In most families where a number of species are utilized, one genus or species tends to predominate. For instance, the following are the dominant genera in some of the most important families: Cassia (Fabaceae), Psychotria (Rubiaceae), Jatropha (Euphorbiaceae), Piper (Piperaceae), and Solanum (Solanaceae). In spite of the prominence of some families and genera, the general pattern we observed was a wide taxonomic distribution of medicinals (Table 4).

Overall, the results show that the vast majority 


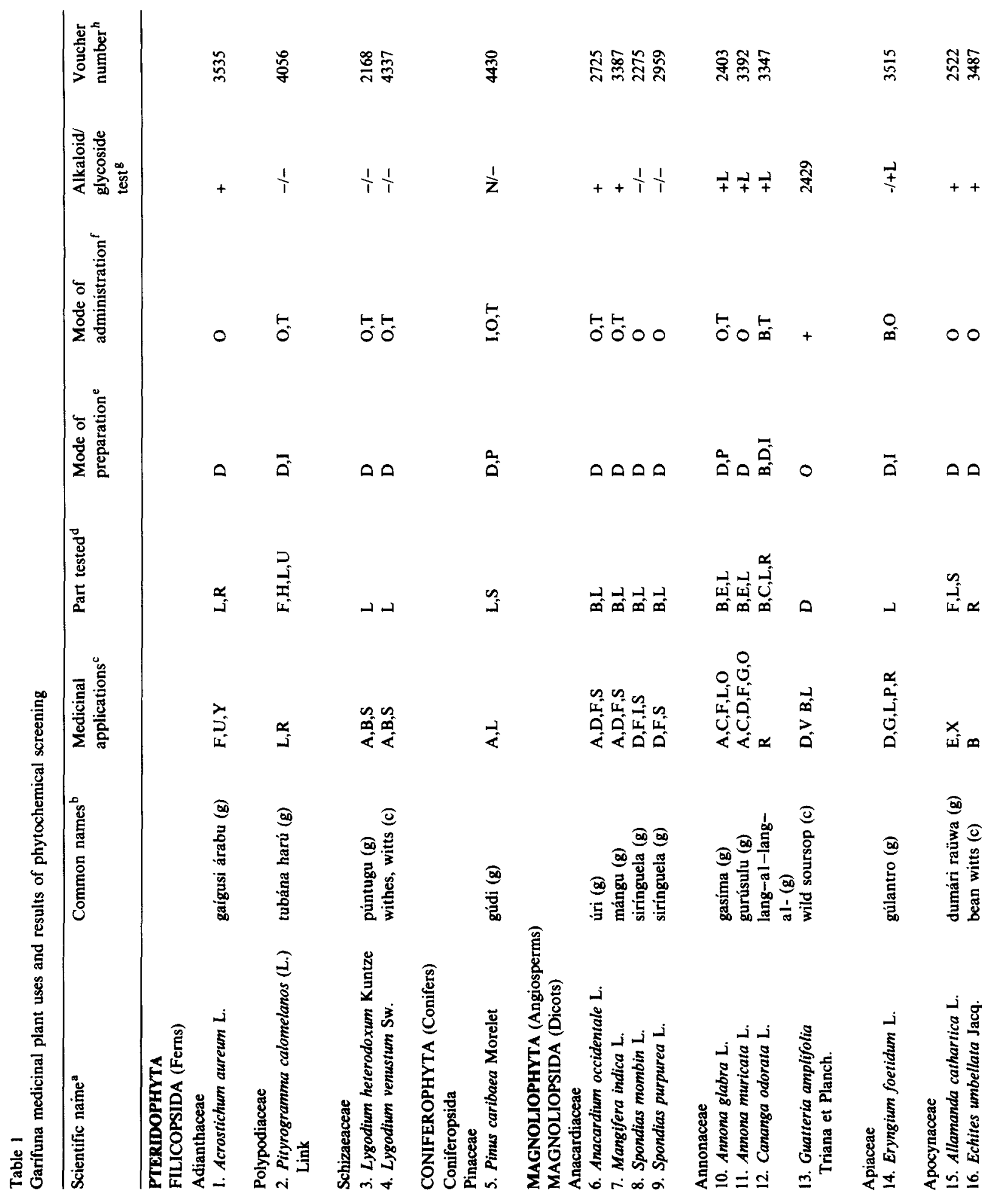




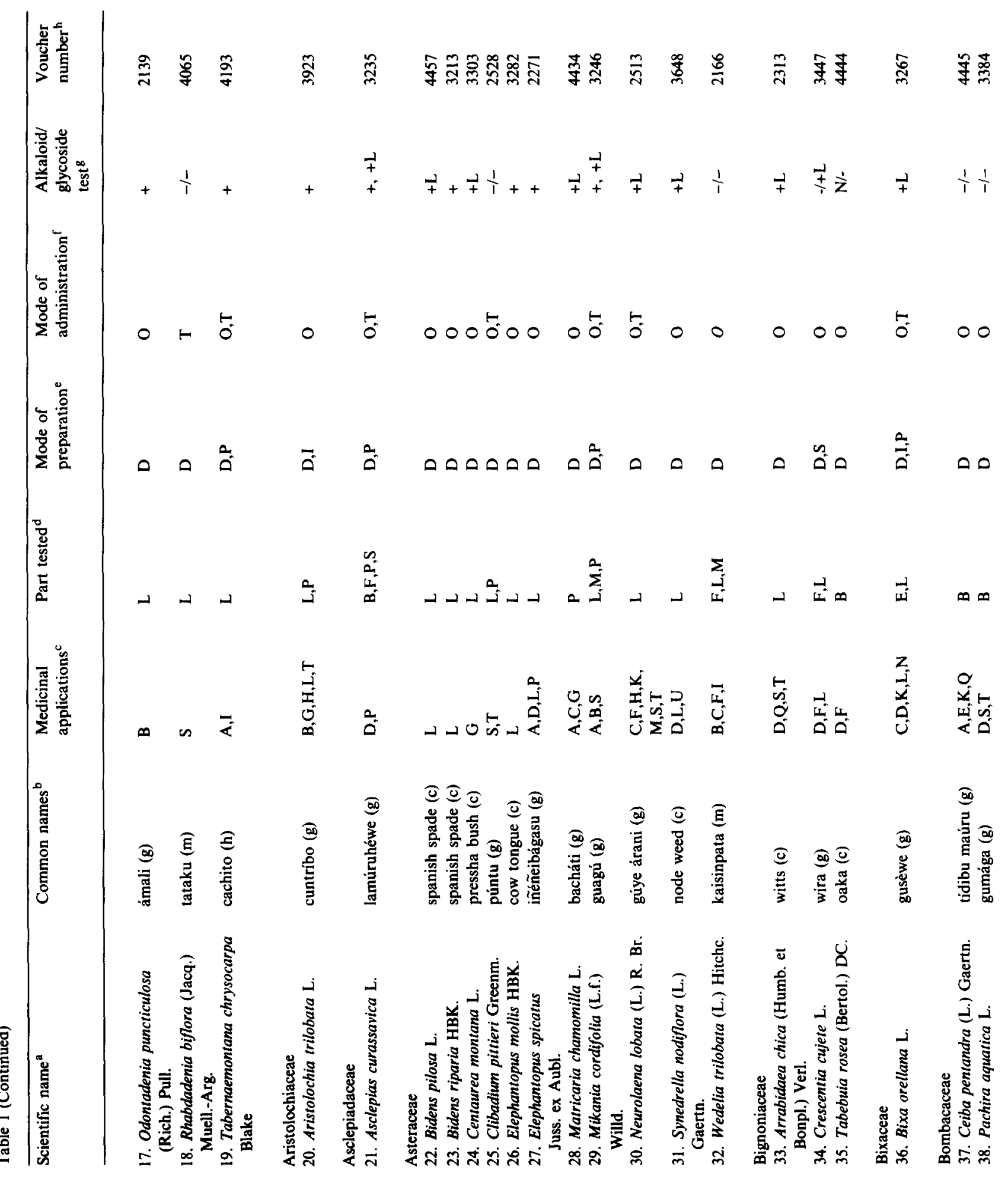




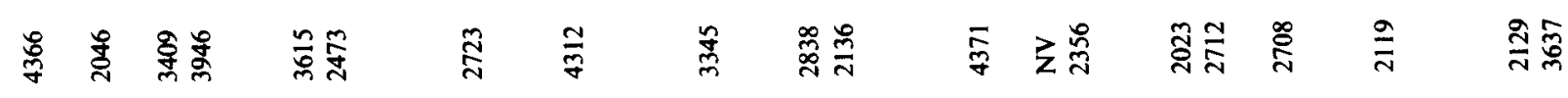

$\stackrel{1}{1}++\frac{1}{1}+\frac{1}{+}+\frac{1}{1} \frac{1}{1}++\frac{1}{1} \frac{1}{1}+\frac{+}{1}+$

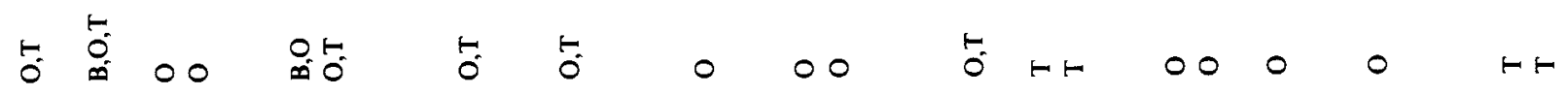

$\hat{\Delta} 000$ 0

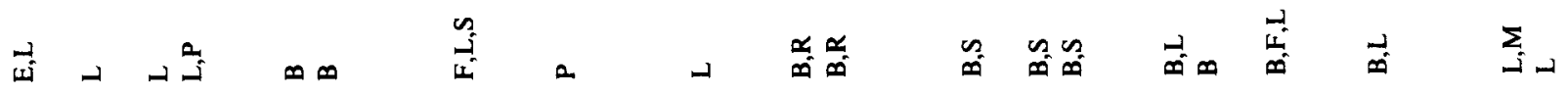

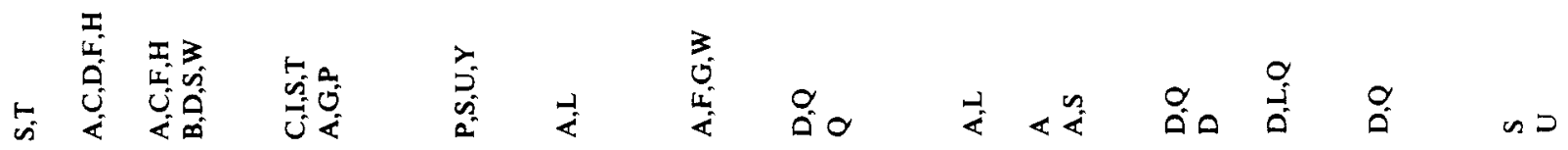

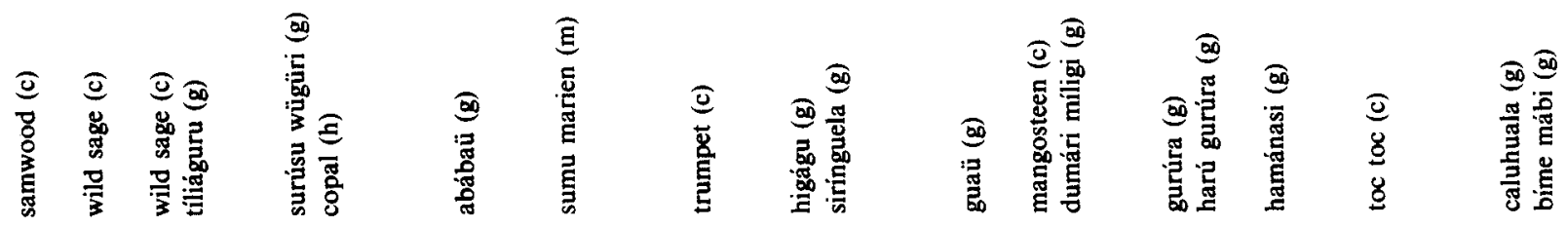

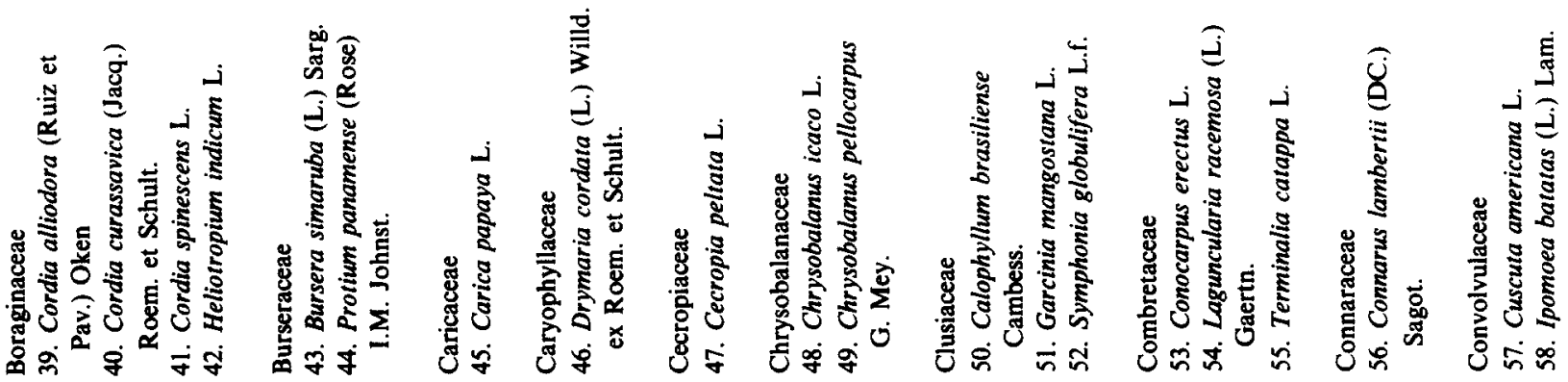




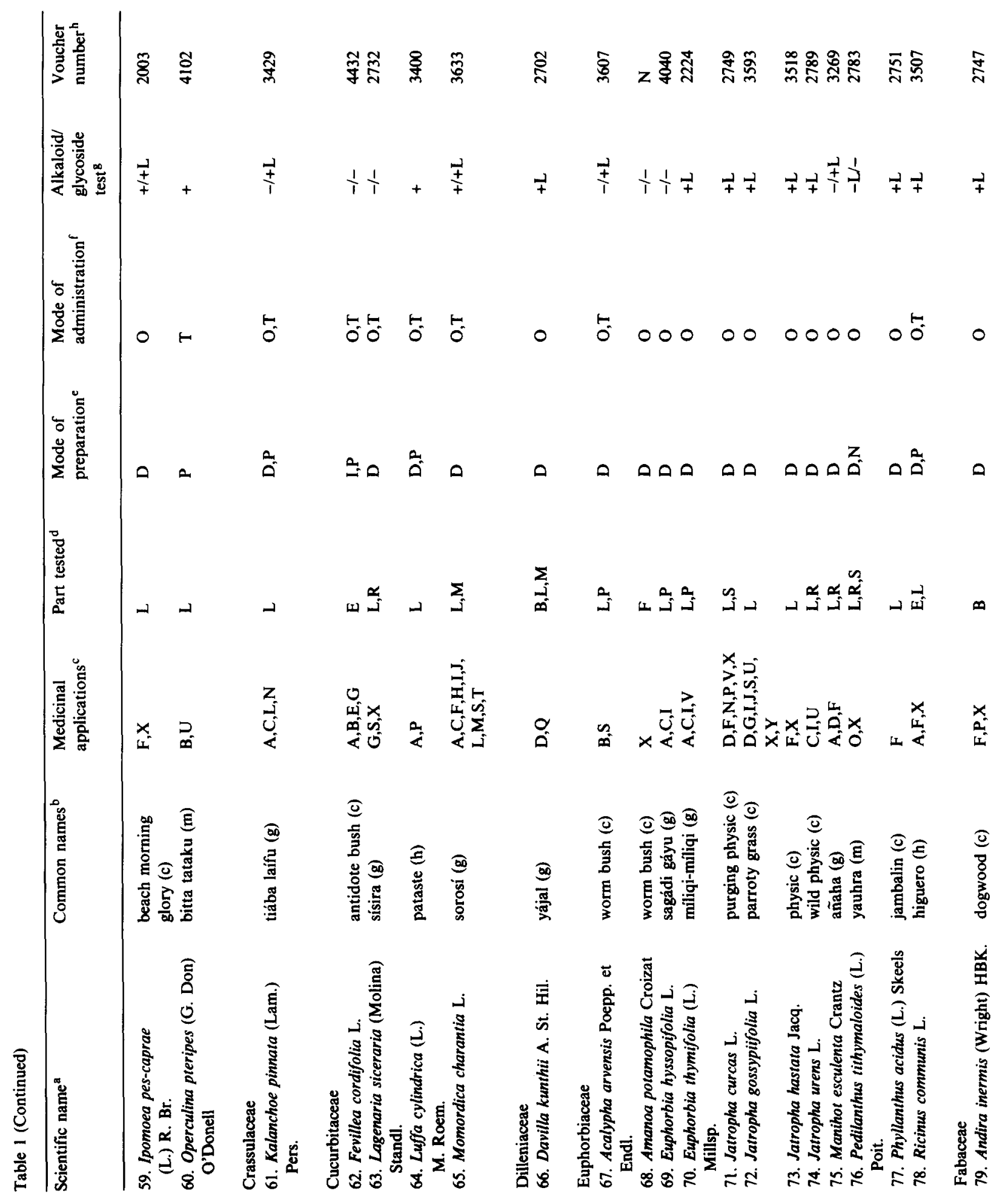




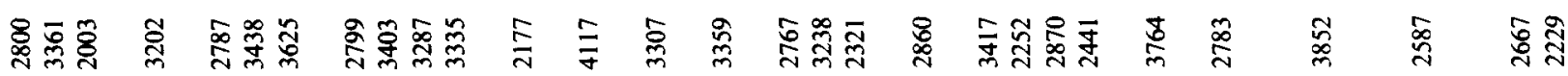

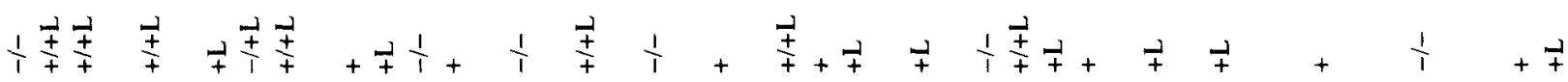

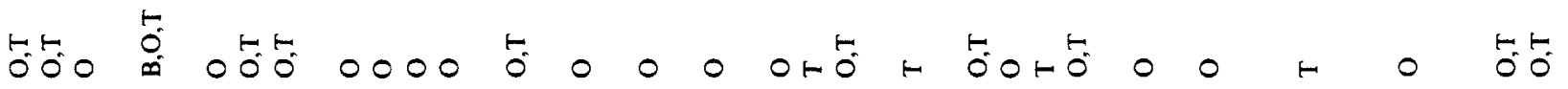

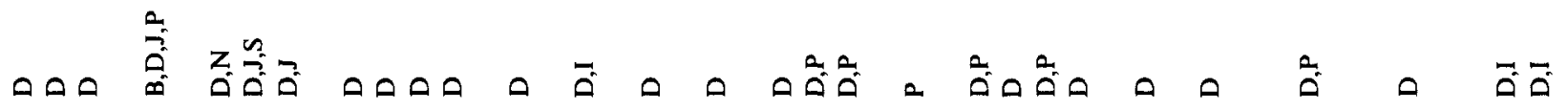

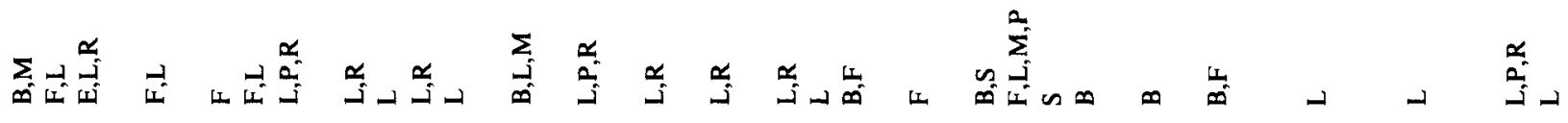

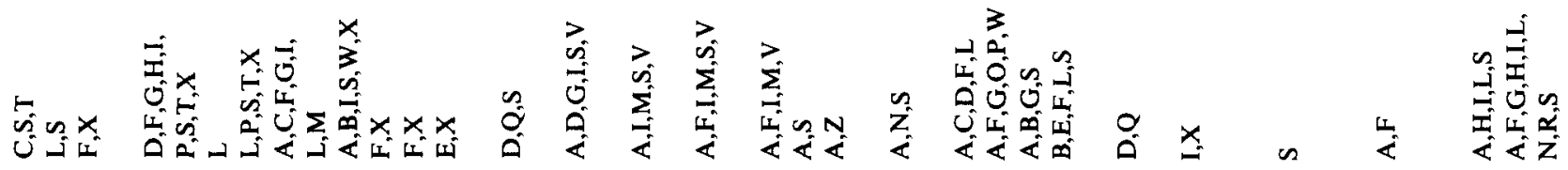

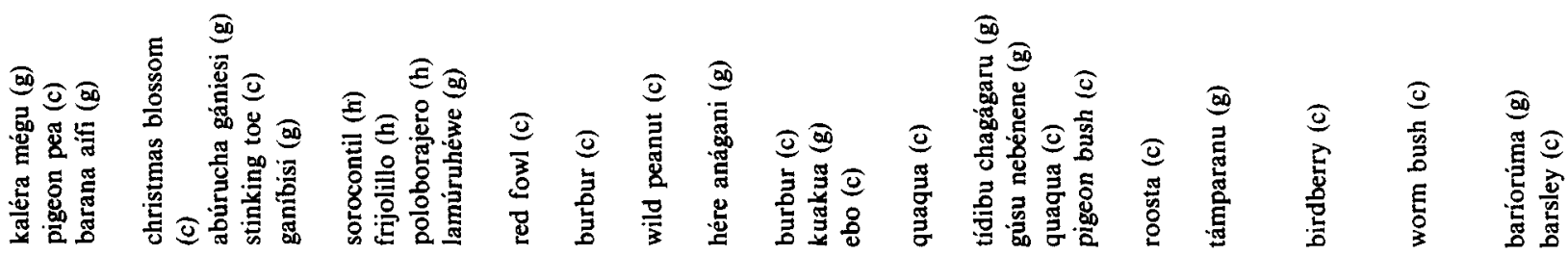

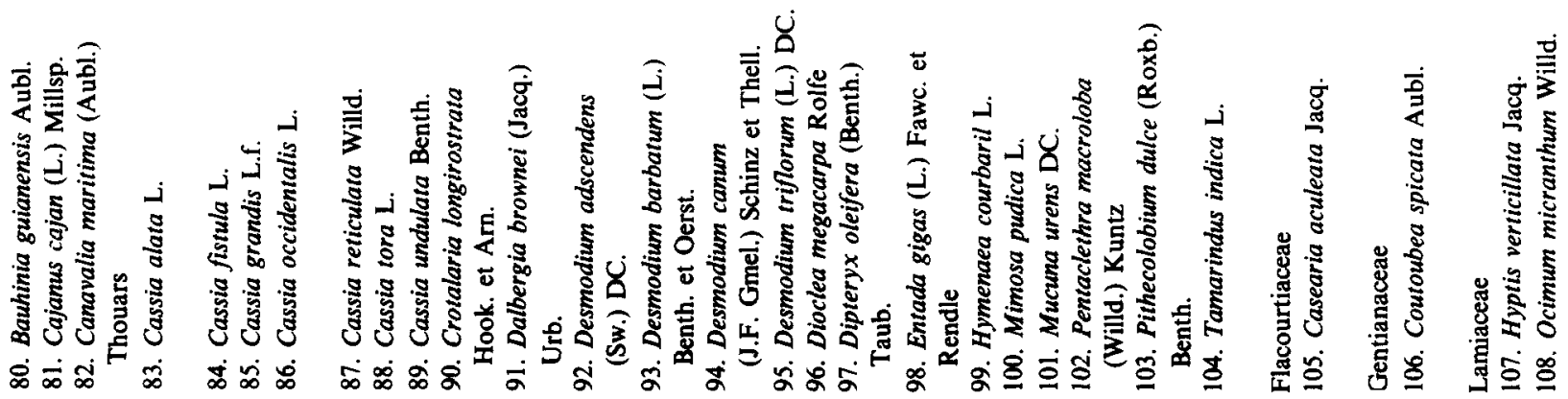




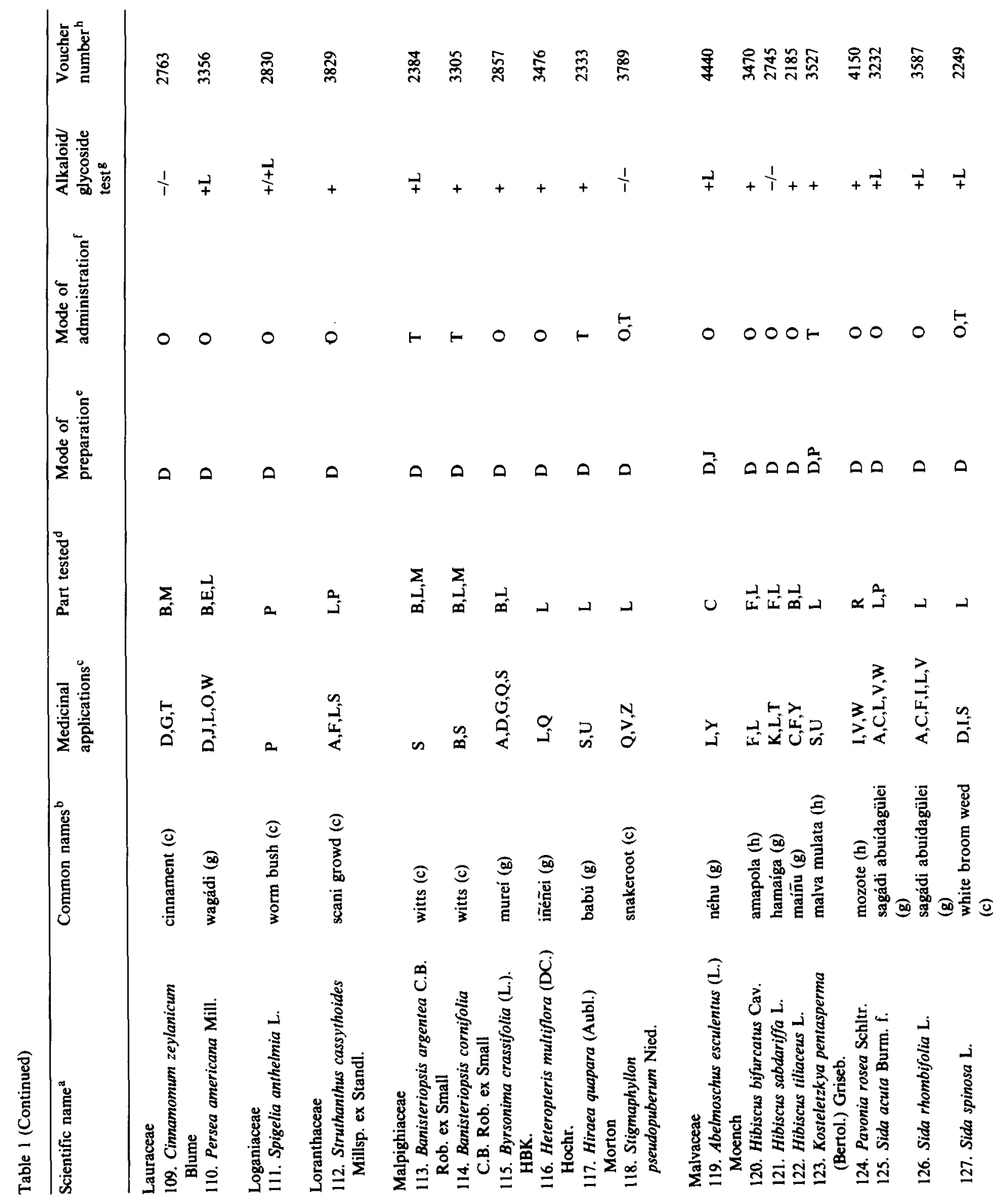




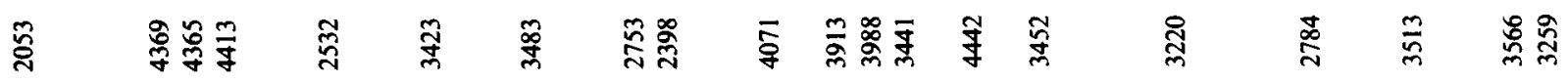

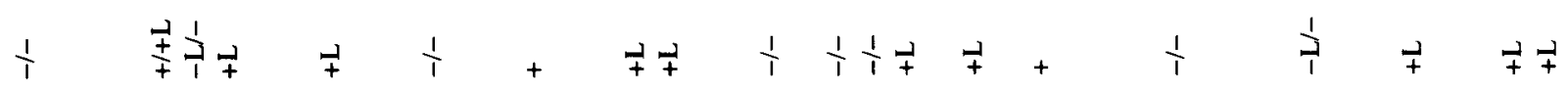

- 000 L

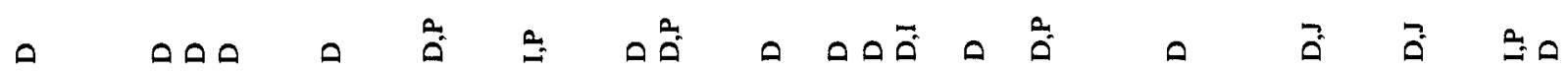

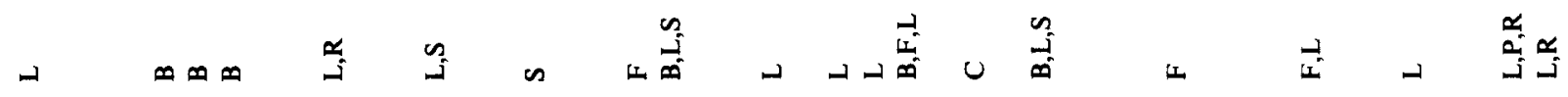

-

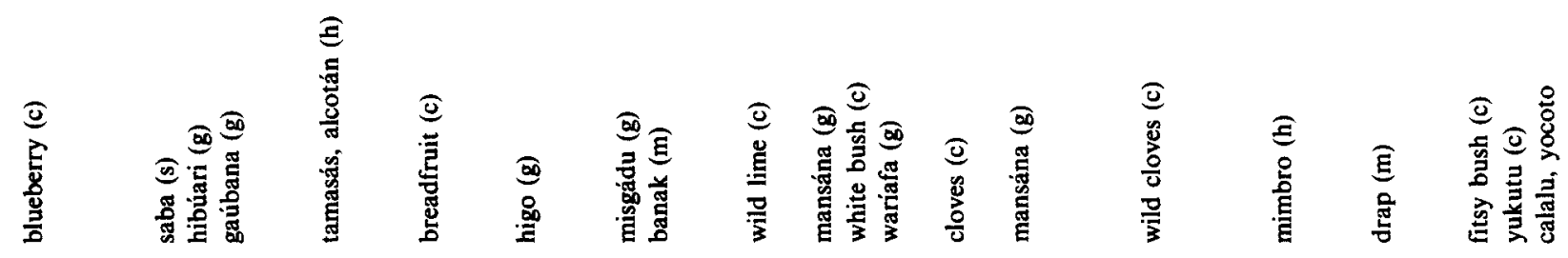

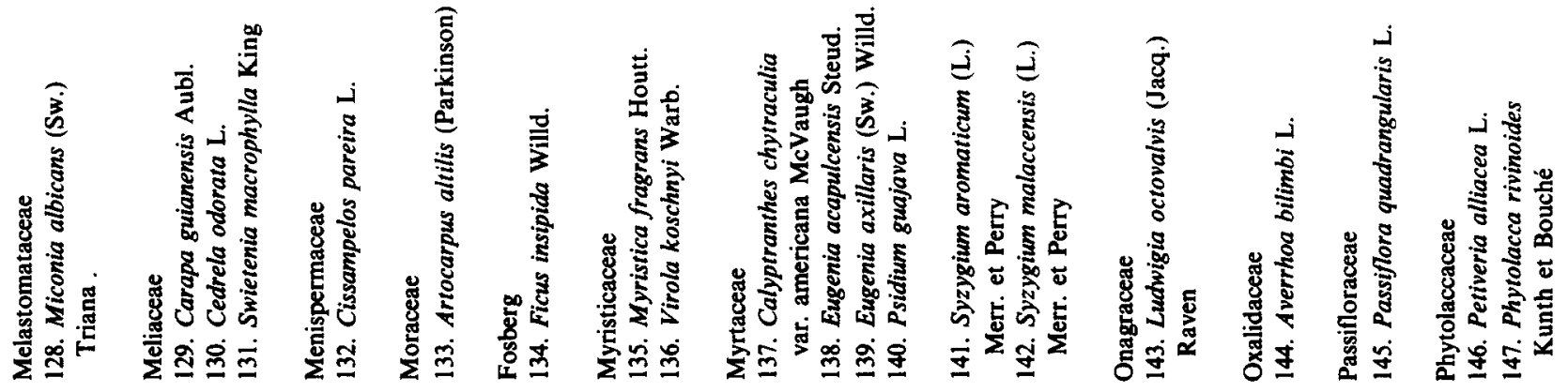




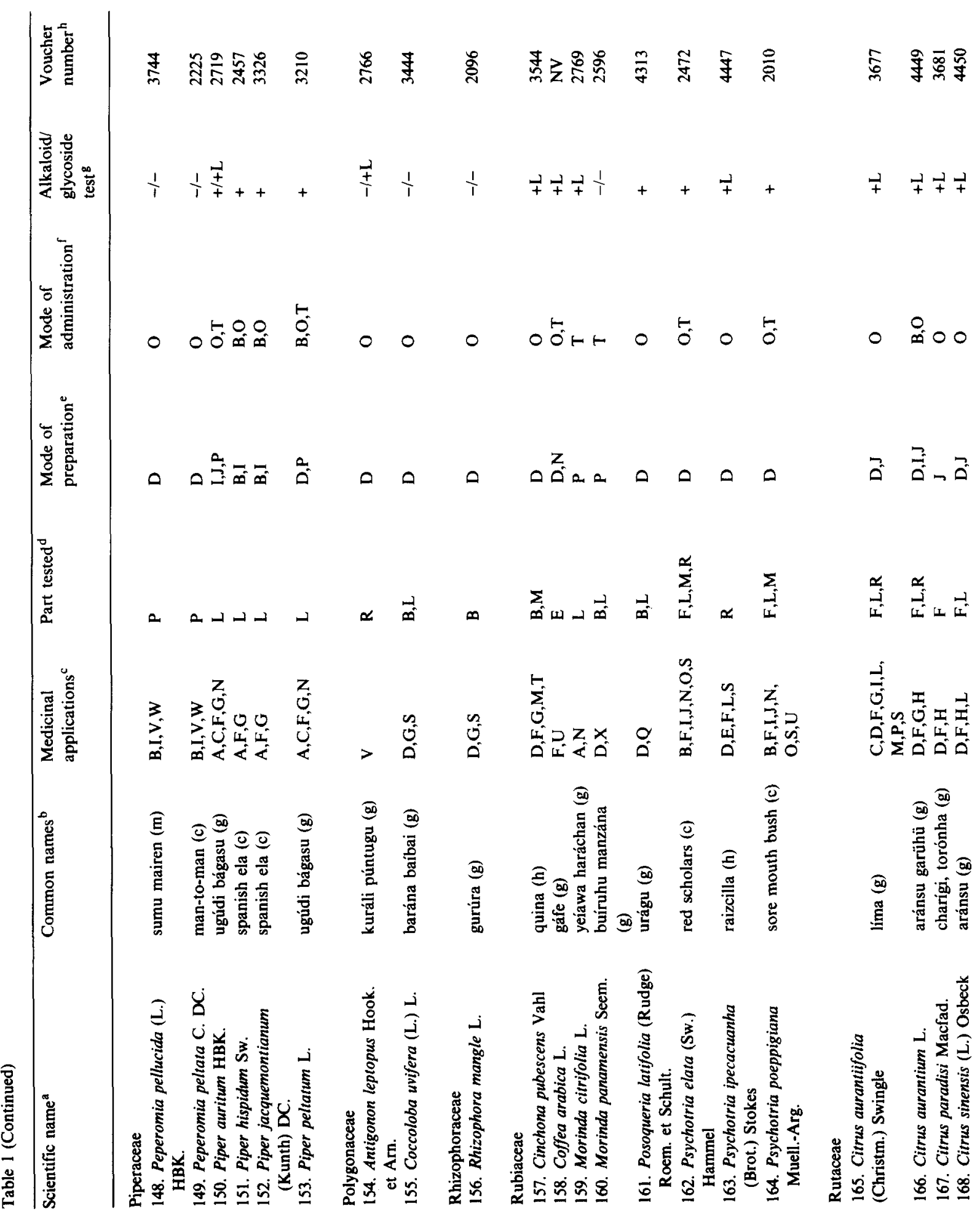




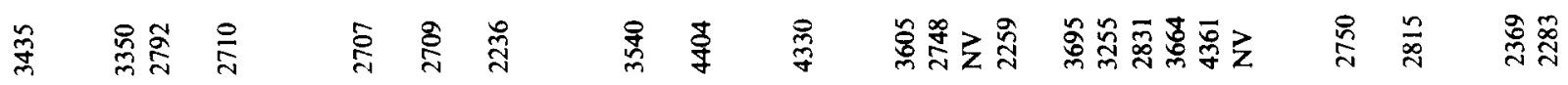

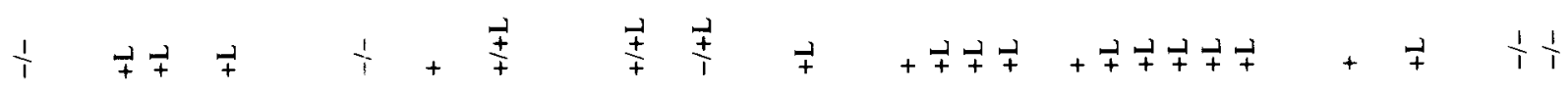

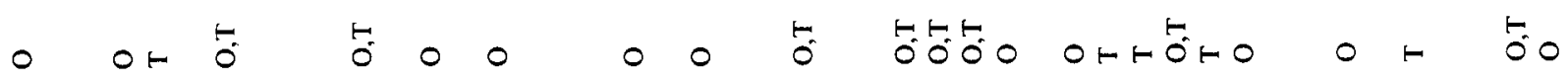

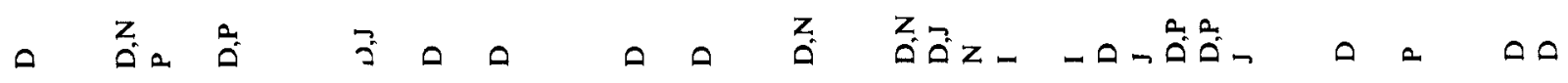

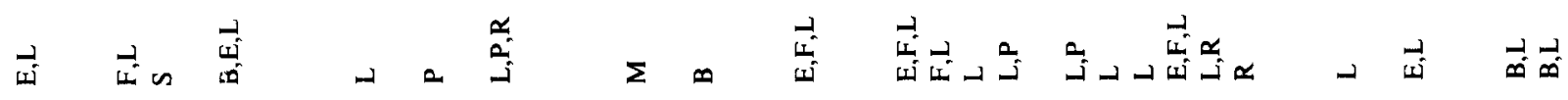

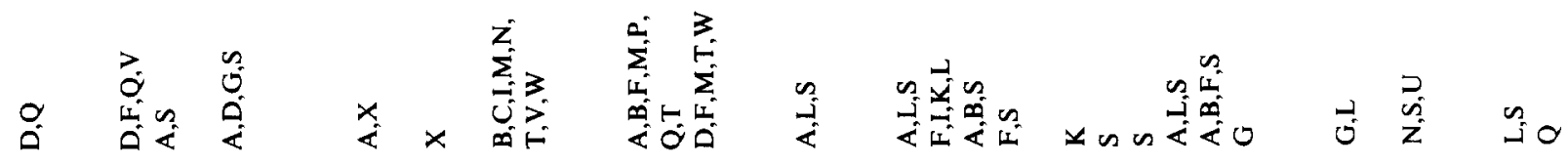

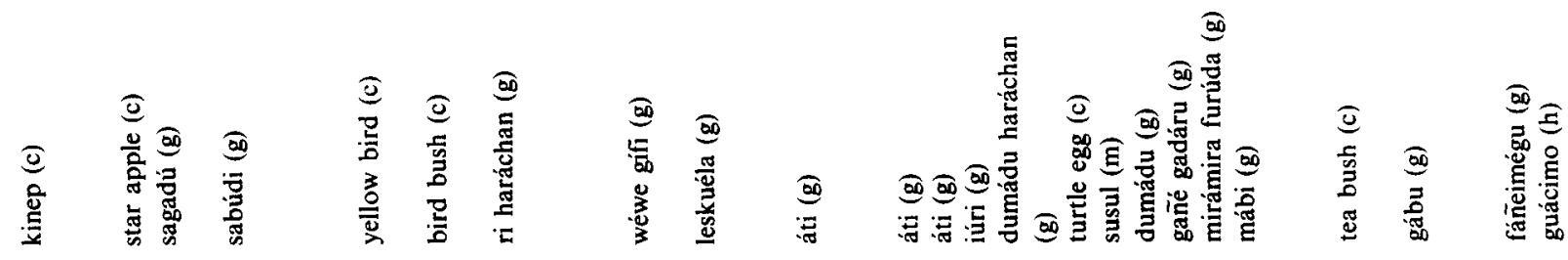

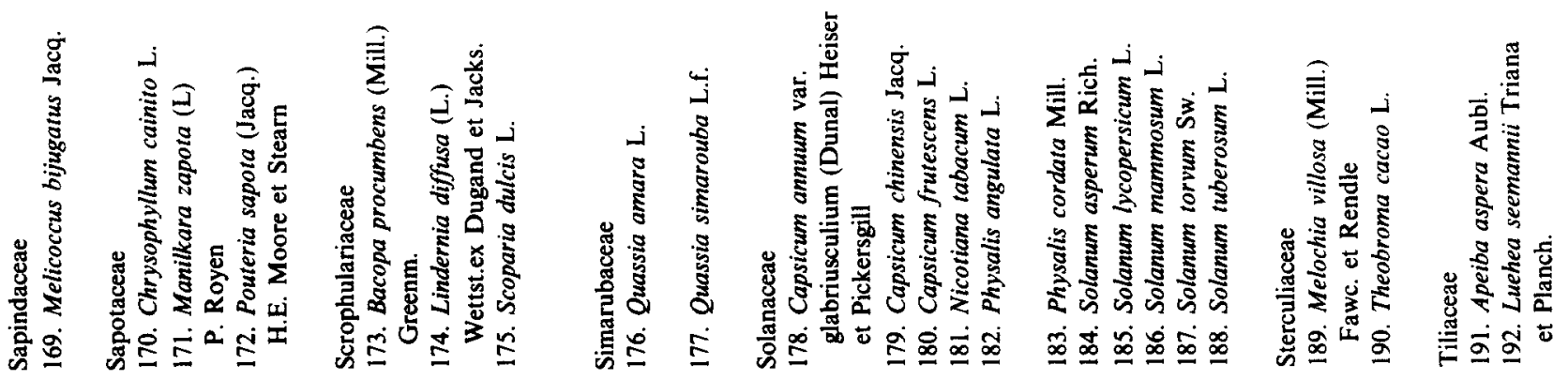




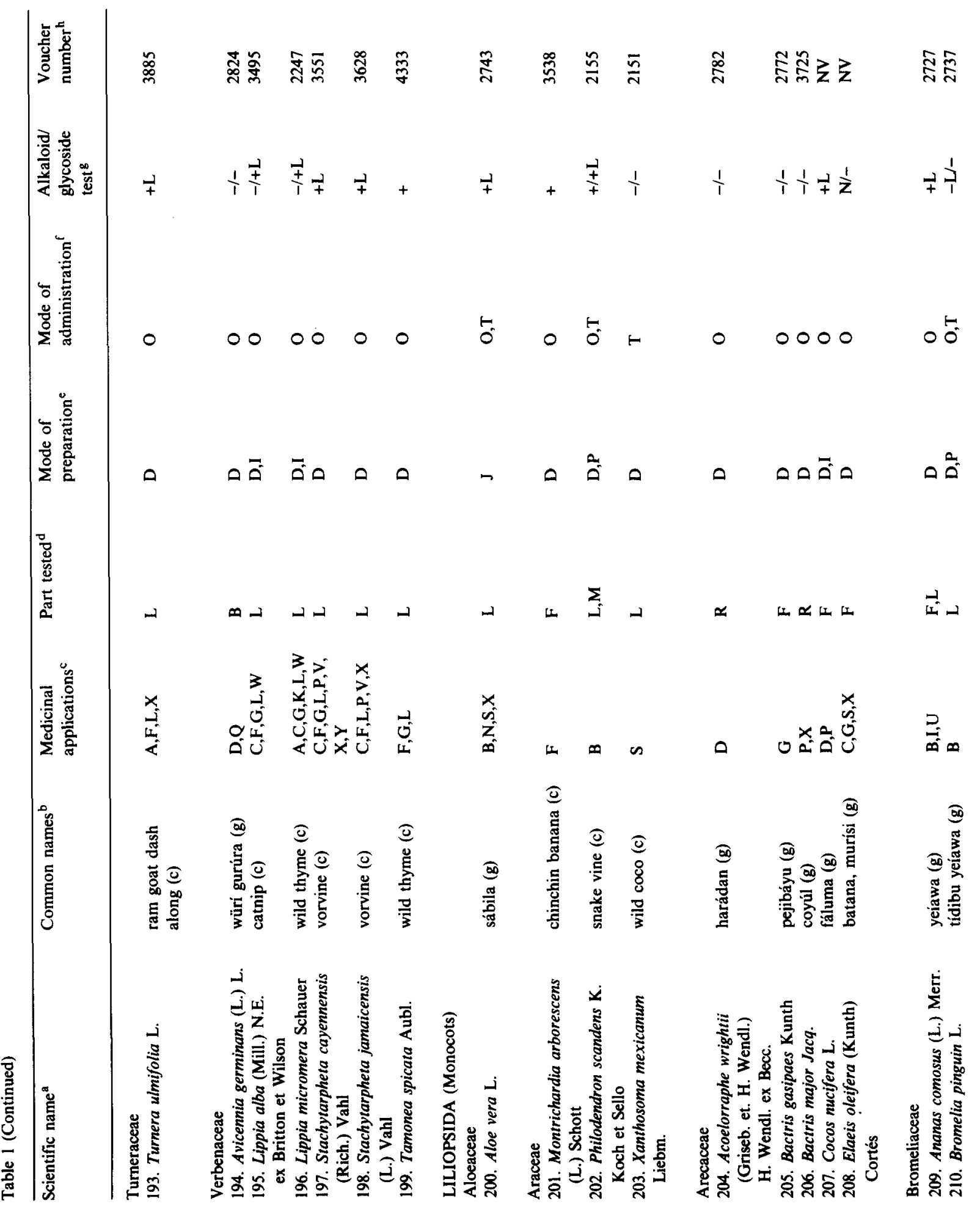




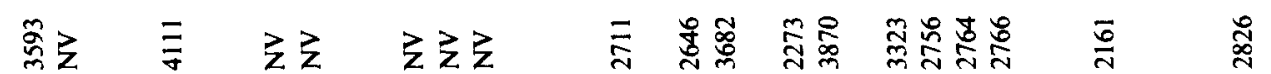

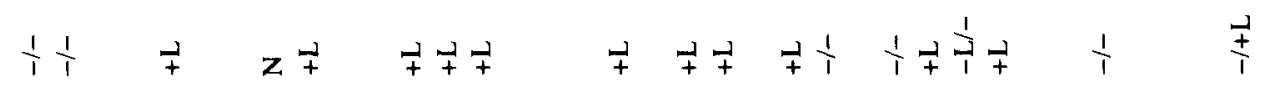

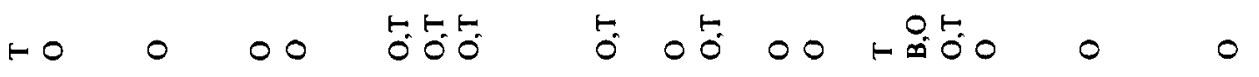

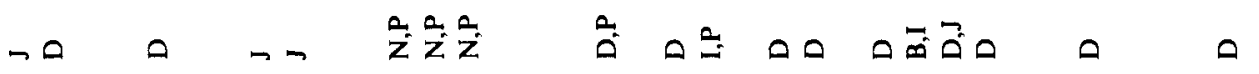

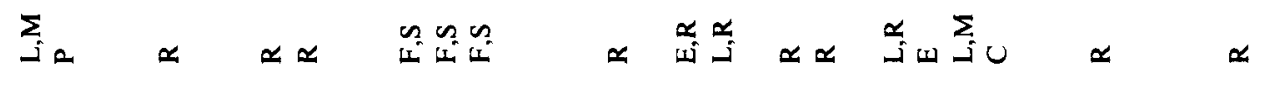

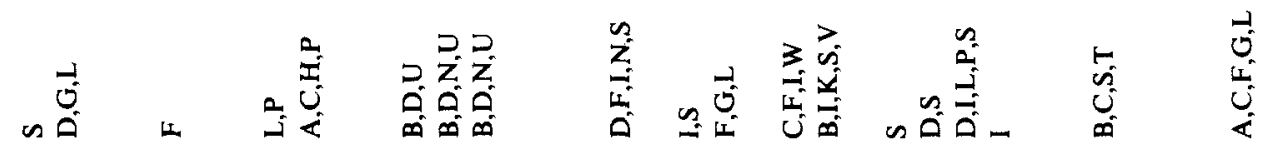

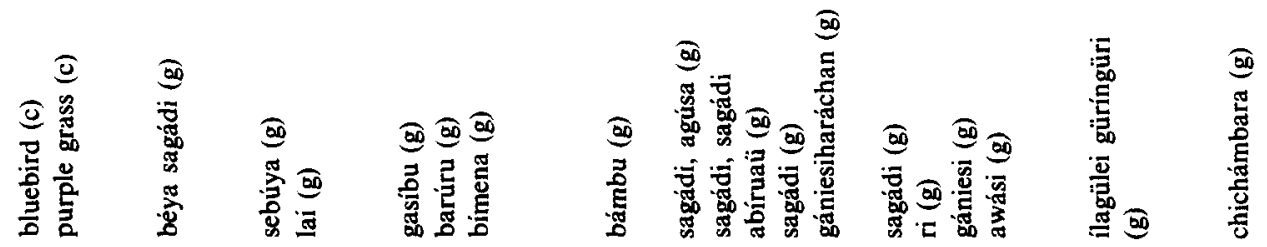

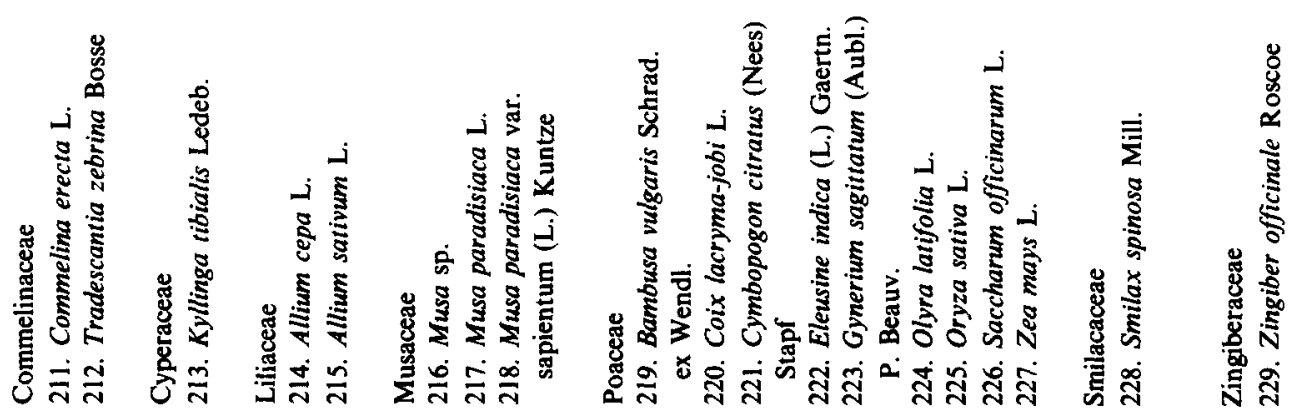




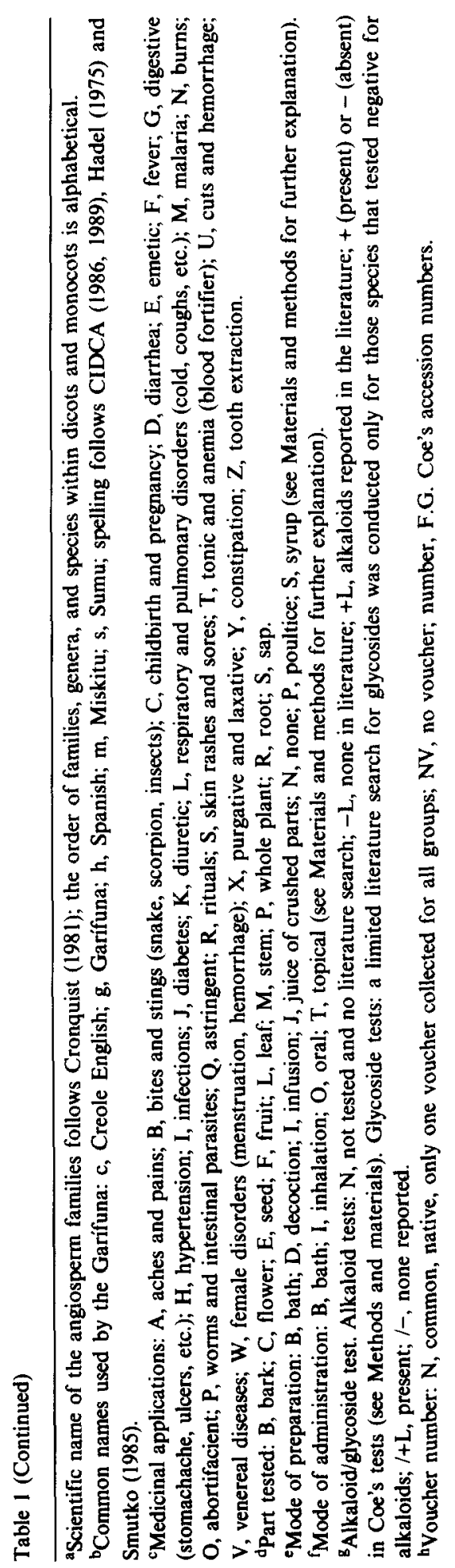


Table 2

Occurrence of alkaloids and glycosides in major taxa: numbers represent species

\begin{tabular}{lllrr}
\hline $\begin{array}{l}\text { Bioactive } \\
\text { compound/source }\end{array}$ & Filicopsida & $\begin{array}{l}\text { Magnoliopsida } \\
\text { (Dicots) }\end{array}$ & $\begin{array}{l}\text { Liliopsida } \\
\text { (Monocots) }\end{array}$ & Total \\
\hline $\begin{array}{lllrl}\text { Alkaloid } \\
\text { Literature }\end{array}$ & 0 & 86 & 15 & 101 \\
Lab/field Test & 1 & 49 & 1 & 51 \\
Total & 1 & 135 & 16 & 152 \\
Glycoside & & & & 12 \\
Literature & 0 & 11 & 1 & 12 \\
Total & 0 & 11 & 17 & 164 \\
Grand total & 1 & 146 & 17 & \\
\hline
\end{tabular}

of the 229 Garifuna medicinal plants contain bioactive compounds. Another sub-sample of the entire list also makes this point. The most commonly used 15 medicinal plant families include some 125 species; more than three-quarters of these species contain alkaloids (Table 4). Cox et al. (1989) and Farnsworth (1984a, 1984b) also report a strong correlation between medicinal plant use and their bioactive compounds. To make this point even clearer, the most popular medicinal species in the Garifuna pharmacopoeia was analyzed. As Table 5 shows, all these 13 'most popular' species (representing 11 families) tested positive for alkaloids. In fact, they have presumably been recognized in other studies, because all but two were already reported in the literature as alkaloid bearing. Another way of making this point is a comparison of the 25 most popular medicinal species with the 25 that are least used

Table 3

Presence of alkaloids in relation to habit of plant

\begin{tabular}{lll}
\hline Habit & $\begin{array}{l}\text { Number of alkaloid } \\
\text { bearing species }\end{array}$ & $\%$ \\
\hline Herb & 66 & 43 \\
Vine & 25 & 17 \\
Shrub & 18 & 12 \\
Tree & 43 & 28 \\
Total & 152 & 100 \\
\hline
\end{tabular}

(Table 6). This is obviously a subjective ranking, but telling nonetheless. More than $95 \%$ of the popular medicinals $(24 / 25)$ bear alkaloids or glycosides, compared with only $68 \%(17 / 25)$ of the less popular species (this difference is highly significant; $/ \mathrm{X}^{2}=4.878 ; P=0.027$ ).

The Garifuna are not alone in claiming the healing properties of certain medicinals. For example, Momordica charantia (plant no. 65 in Table 1) is also the most popular medicinal among the Miskitu, Sumu, and Rama of eastern Nicaragua. It is also widely used in Mexico, Belize, Honduras, Costa Rica, Panama and the Caribbean (Duke, 1972, 1994; Morton, 1981; Martínez, 1991; García, 1992; Balick and Arvigo, 1993; Duke and Vasquez, 1994). In China, $M$. charantia is used to treat more than 10 ailments (Yang and Walters, 1992). In Fiji (Cambie and Ash, 1994) and in Sri Lanka (Tennekoon et al., 1994) it is used to treat diabetes. Cassia occidentalis (plant no. 86 in Table 1) is another popular medicinal used by the Garifuna and other indigenous groups of both the Old World and New World tropics. In the New World, this species is widely used from Mexico to Colombia and in the Caribbean (Duke, 1972, 1994; Morton, 1981; Martínez, 1991; García, 1992; Balick and Arvigo, 1993; Duke and Vasquez, 1994). In Fiji, $C$. occidentalis is used as a pediatric anticonvulsive and sedative (Cambie and Ash, 1994). This species is also used medicinally in the Philippines, China, and Guam (Perry, 1980; Concha, 1982). In 
Table 4

Plant families of Garifuna medicinals with the largest number of alkaloid-bearing species

\begin{tabular}{|c|c|c|c|c|c|c|}
\hline \multirow[t]{2}{*}{ Family } & \multirow{2}{*}{$\begin{array}{l}\text { Number of } \\
\text { species used }\end{array}$} & \multirow{2}{*}{$\begin{array}{l}\text { Reported in } \\
\text { literature }\end{array}$} & \multicolumn{2}{|c|}{ Lab/field results } & \multirow{2}{*}{$\begin{array}{l}\text { Total alkaloid- } \\
\text { bearing species }\end{array}$} & \multirow{2}{*}{$\begin{array}{l}\% \text { with } \\
\text { alkaloids }\end{array}$} \\
\hline & & & Positive & Negative & & \\
\hline Annonaceae & 4 & 3 & 1 & 0 & 4 & 100 \\
\hline Apocynaceae & 5 & 0 & 4 & 1 & 4 & 80 \\
\hline Asteraceae & 11 & 6 & 3 & 2 & 9 & 82 \\
\hline Boraginaceae & 4 & 1 & 2 & 1 & 3 & 75 \\
\hline Convolvulaceae & 4 & 2 & 2 & 0 & 4 & 100 \\
\hline Curcurbitaceae & 4 & 1 & 1 & 2 & 2 & 50 \\
\hline Euphorbiaceae & 12 & 7 & 0 & 5 & 7 & 58 \\
\hline Fabaceae & 26 & 15 & 5 & 6 & 20 & 77 \\
\hline Malpighiaceae & 6 & 1 & 4 & 1 & 5 & 83 \\
\hline Malvaceae & 9 & 4 & 4 & 1 & 8 & 89 \\
\hline Piperaceae & 6 & 1 & 3 & 2 & 4 & 67 \\
\hline Poaceae & 9 & 6 & 0 & 3 & 6 & 67 \\
\hline Rubiaceae & 8 & 4 & 3 & 1 & 7 & 87 \\
\hline Solanaceae & 11 & 9 & 2 & 0 & 11 & 100 \\
\hline Verbenaceae & 6 & 2 & 1 & 3 & 3 & 50 \\
\hline Total & 125 & 62 & 35 & 28 & 97 & \\
\hline
\end{tabular}

Thailand, $C$. occidentalis is used to treat malaria, digestive disorders, urinary problems, bladder stones, and as a tonic and diuretic (Anderson, 1993). The independent uses of $M$. charantia and C. occidentalis and other species by many people across such a broad range of geographic regions supports the assumption that bioactive compounds of some value may be present.

Another simple analysis of the data was to look at the distribution of alkaloids and glycosides in relation to mode of application. By considering the primary mode of application (obviously, many medicinals have multiple uses and more than one mode of application), all but nine of the medicinals could be classified. Table 7 shows that most are primarily administered orally; most (75\%) such medicines bear bioactive principles. However, most $(70 \%)$ of those applied topically also bear such substances. Thus, there is no difference $\left(/ \mathrm{X} /{ }^{2}=0.111, \quad P=0.739\right)$ in the possible physiological impact of medicinals used in either way. Perhaps one would not expect any such differences because many topical applications are associated with wounds or skin diseases where bioactive compounds get through the skin even without a penetration enhancer.
Overall, baseline alkaloid screening as done in this survey is an important starting point for more detailed investigations of the pharmacological activity of bioactive principles of medicinals. Our results and those of others (Farnsworth, 1984a, 1984b; Schultes, 1986; Cox et al., 1989; Balick, 1990), show that screening of the ethnobotanical lore of indigenous people provides a rapid and effective means of examining a flora for bioactive compounds. We found that more than $70 \%$ of the plant species used by the Garifuna of eastern Nicaragua as medicinals contained alkaloids or glycosides. It is unlikely that a random screening of the local flora would have resulted in such a high success rate. In several studies the percentage of species identified as alkaloid-bearing is considered higher in ethnobotanical screening than would have been found in a random survey (Arthur and Cheung, 1960; Kiang et al., 1961; Amarasingham et al., 1964; Hultin and Torssell, 1965; Farnsworth, 1988).

What about the remaining $25 \%-30 \%$ of the medicinals that tested negative for alkaloids? Our tests may not have detected alkaloids present, but that seems unlikely. These species may contain other biologically active secondary compounds 
Table 5

Significant Garifuna medicinals (based on number of ailments treated and subjective interpretation of their importance)

\begin{tabular}{|c|c|c|c|}
\hline Scientific name & $\begin{array}{l}\text { Number } \\
\text { of } \\
\text { ailments } \\
\text { treated }\end{array}$ & Rating $^{\mathrm{a}}$ & $\begin{array}{l}\text { Alka- } \\
\text { loid } \\
\text { tests }^{b}\end{array}$ \\
\hline \multicolumn{4}{|l|}{ ASTERACEAE } \\
\hline Neurolaena lobata & 7 & $\mathbf{H}$ & $\mathbf{L}$ \\
\hline \multicolumn{4}{|l|}{ CUCURBITACEAE } \\
\hline Momordica charantia & 10 & $\mathbf{H}$ & $\mathbf{L}$ \\
\hline \multicolumn{4}{|l|}{ EUPHORBIACEAE } \\
\hline Jatropha gossypiifolia & 8 & $\mathbf{M}$ & $\mathbf{L}$ \\
\hline \multicolumn{4}{|l|}{ FABACEAE } \\
\hline Cassia alata & 9 & $\mathbf{H}$ & $\mathbf{L}$ \\
\hline Cassia occidentalis & 7 & $\mathbf{H}$ & $\mathbf{L}$ \\
\hline \multicolumn{4}{|l|}{ LAMIACEAE } \\
\hline Ocimum micranthum & 9 & $\mathbf{M}$ & $\mathbf{L}$ \\
\hline \multicolumn{4}{|l|}{ MYRTACEAE } \\
\hline Psidium guajava & 8 & $\mathbf{M}$ & $\mathbf{L}$ \\
\hline \multicolumn{4}{|l|}{ RUBIACEAE } \\
\hline Psychotria elata & 7 & $\mathrm{H}$ & + \\
\hline Psychotria poeppigiana & 8 & $\mathrm{H}$ & + \\
\hline \multicolumn{4}{|l|}{ RUTACEAE } \\
\hline Citrus aurantiifolia & 9 & $\mathbf{H}$ & $\mathrm{L}$ \\
\hline \multicolumn{4}{|l|}{ SCROPHULARIACEAE } \\
\hline Scoparia dulcis & 8 & $\mathbf{H}$ & $\mathbf{L}$ \\
\hline \multicolumn{4}{|l|}{ SIMARUBACEAE } \\
\hline Quassia amara & 7 & $\mathbf{H}$ & $\mathbf{L}$ \\
\hline \multicolumn{4}{|l|}{ VERBENACEAE } \\
\hline Stachytarpheta cayenensis & 8 & $\mathbf{M}$ & $\mathbf{L}$ \\
\hline
\end{tabular}

${ }^{\mathrm{a}} \mathrm{H}$, high; M, medium; L, low; based on $\mathrm{F}$. Coe's interviews and field experience.

${ }^{b} \mathrm{~L}$, alkaloid reported in the literature; + present in Coe's tests.

that together with essential fatty acids, mineral nutrients, and vitamins present, may be of value. Johns (1990) argues that many medicinals are of value not because they are antagonistic to disease organisms, or act as stimulants to organ systems, but because they provide some essential fatty acids, mineral nutrients, or vitamins that are in
Table 6

Alkaloids/glycosides and extent of application

\begin{tabular}{lll}
\hline Popularity of medicinals & \multicolumn{2}{l}{ Alkaloids/glycosides ${ }^{\text {a }}$} \\
\cline { 2 - 3 } & Present & Absent \\
\hline Leading 25 species & 24 & 1 \\
Least used 25 species & 17 & 8 \\
\hline
\end{tabular}

$\chi^{2}=4.878 ; P=0.0272$.

${ }^{a}$ Data on glycosides are based on literature reports.

low supply in the regular food system. For example, Smilax spinosa (plant no. 228 in Table 1) is rich in essential fatty acids, and Bromelia pinguin (plant no. 210 in Table 1) is a good source of minerals and vitamins. Of course, not all the medicinals will have either traditional medicinal value or supply the missing nutrients. Some will be valueless, and others of importance psychologically - certain 'prescriptions' provide healing power simply because a respected practitioner in the community prescribed them (just as in Western medicine).

Nonetheless, the presence of bioactive compounds in the vast majority of Garifuna medicinals may explain their therapeutic use. These extensive field-based studies are a necessary first step in the search for new biologically active molecules from natural products. Tests to explore the pharmacological activity of the compounds are the required next logical steps in determining the efficacy and application of the Garifuna pharmacopoeia.

Table 7

Alkaloids/glycosides and mode of administration (nine species could not be placed in either the oral or the topical category)

\begin{tabular}{lcc}
\hline Mode of administration & \multicolumn{2}{c}{ Alkaloids/Glycosides ${ }^{\mathbf{a}}$} \\
\cline { 2 - 3 } & Present & Absent \\
\hline Oral & 128 & 45 \\
Topical & 33 & 14 \\
Other & 3 & 6 \\
\hline
\end{tabular}

$\chi^{2}=0.111 ; P=0.7395$.

${ }^{a}$ Data on glycosides are based on literature reports. 
Another goal of this work has been to document the use of plants in traditional Garifuna culture a culture that, like many, is disappearing rapidly with acculturation. The next step in that effort is the translation and dissemination of these studies to the Garifuna communities. That effort is underway and, although less sophisticated than the pharmacological trials, is equally important.

\section{Acknowledgements}

This study was partially supported by grants from the National Science Foundation and The University of Connecticut Research Foundation. We are most grateful to the Garifuna people for sharing their ethnobotanical knowledge with us. The field assistance of Far Blanford, Dale DeSousa, and Rodney Martin is deeply appreciated. We thank the staffs of CIDCA (Centro de Investigación y Documentación de la Costa Atlántica) and FADCANIC (Fundación Para la Autonomia $y$ Desarrollo de la Costa Atlántica de Nicaragua) for their help. Many specialists provided assistance in the identification of voucher herbarium specimens: William D'Arcy of the Missouri otanical Garden (MO), Rupert Barneby of the New York Botanical Garden (NY), Gerrit Davidse (MO), James Grimes (NY), Helen Kennedy of the University of British Columbia at Vancouver (UBC), Ronald Leisner (MO), Michael Nee (NY), Amy Pool (MO), Velva Rudd of California State University at Northridge (SFV), George Schatz (MO), Warren D. Stevens (MO), Charlotte M. Taylor (MO), and Iván Valdespino (NY). Thanks to Michael Edwards and Kent Holsinger for their comments on the manuscript. We thank Ellie DeCarli and Mary Jane Spring for help with tables and figures.

\section{References}

Amarasingham, R.D., Bisset, N.G., Millard, A.H. and Woods, M.C. (1964) A phytochemical survey of Malaya. III. Alkaloids and saponins. Economic Botany 18, 270-278.

Anderson, E.F. (1993) Plants and People of the Golden Triangle: Ethnobotany of the Hill Tribes of Northeastern Thailand. Dioscorides Press, Portland, OR.

Arthur, H.R. and Cheung, H.T, (1960) A phytochemical survey of Hong Kong medicinal plants. Journal of Pharmacy and Pharmacology 12, 567-570.
Balick, M.J. (1990) Ethnobotany and the identification of therapeutic agents from the rainforest. In: D.J. Chadwick and J. Marsh (Eds.), Bioactive Compounds from Plants. Ciba Foundation Symposium, No. 154. John Wiley and Sons, Chichester and New York, pp. 22-39.

Balick, M.J. and Arvigo, R. (1993) Rainforest Remedies: One Hundred Healing Herbs of Belize. Lotus Press, Twin Lakes, WI.

Bridson, D. and Forman, L. (1992) The Herbarium Handbook. Royal Botanic Gardens, Kew.

Cambie, R.C. and Ash, J. (1994) Fijian Medicinal Plants. CSIRO, Australia.

Caufield, C. (1991) In the Rainforest. The University of Chicago Press, Chicago.

CIDCA (Centro de Investigación y Documentación de la Costa Atlántica) (1986) Diccionario Elemental: Miskito-Español/Español-Miskito. MIDINRA, Managua.

CIDCA (Centro de Investigación y Documentación de la Costa Atlántica) (1989) Diccionario Elemental del Ulwa: Sumu Meridional. Centro de Ciencia Cognitiva, Instituto Tecnológico de Massachusetts, Cambridge, MA.

Coe, F.G. and Anderson, G.J. (1996) Ethnobotany of the Garifuna of eastern Nicaragua. Economic Botany 50, 71-103.

Concha, J.A. (1982) Philippine National Formulary, 2nd Edn. National Science and Technology Authority, Manila.

Cordell, G.A. (1981) Introduction to the Alkaloids: a Biogenetic Approach. John Wiley and Sons, New York.

Cox, P.A., Sperry, L.R., Tuominen, M. and Bohlin, L. (1989) Pharmacological activity of the Samoan ethnopharmacopoeia. Economic Botany 43, 487-497.

Crawford, M. (1984) Current Development in Anthropological Genetics: Black Caribs. A Case Study in Biocultural Adaptation, Vol. 3. Plenum Press, New York, pp. 1-9.

Cronquist, A. (1981) An Integrated System of Classification of Flowering Plants. Columbia University Press, New York.

Davidson, W.V. (1976) Dispersal of the Garifuna in the Western Caribbean. Actes du XLII Congress International Des Americanists, Vol. 6, Paris, pp. 467-474.

Davidson, W.V. (1980) The Garifuna of Pearl Lagoon ethnohistory of an Afro-Amerindian enclave in Nicaragua. Ethnohistory 27, 31-47.

Duke, J.A. (1972) Isthmian Ethnobotanical Dictionary. Fulton, MD, $96 \mathrm{pp}$.

Duke, J.A. (1994) Chemical Composition of Belizean Plants Discussed in Rainforest Remedies: One Hundred Healing Herbs of Belize. New York Botanical Garden, New York.

Duke, J.A. and Vasquez, R. (1994) Amazonian Ethnobotanical Dictionary. CRC Press, Boca Raton, FL.

Farnsworth, N.R. (1966) Biological and Phytochemical Screening of Plants. Journal of Pharmaceutical Sciences 55, 225-276.

Farnsworth, N.R. (1984a) The role of medicinal plants in drug development. In: P. Krogsgaard-Larsen, S. Brogger Christensen and H. Kofod (Eds.), Natural Products and Drug Development. Ballier, Tindall, and Cox, London, pp. 8-98. 
Farnsworth, N.R. (1984b) How can the well be dry when it is filled with water? Economic Botany 38, 4-13.

Farnsworth, N.R. (1988) Screening plants for new medicines. In: E.O. Wilson (Ed.), Biodiversity. National Academy Press, Washington, DC, pp. 83-97.

Farnsworth, N.R. and Morris, R.W. (1976) Higher plants: the sleeping giants of drug development. American Journal of Pharmacy 148, 46-52.

Farnsworth, N.R. and Soejarto, D.D. (1985) Potential consequence of plant extinction in the United States on the current and future availability of prescription drugs. Economic Botany 39, 231-240.

Garcia, H. (1992) Flora Medicinal de Colombia. Tomo I. Tercer Mundo Editores, Bogotá, Colombia.

Hadel, R.E. (1975) A Dictionary of Central American Carib. 3 Vols. BISRA, Belize City.

Hale, C. and Gordon, E.T. (1987) Costeño demography: historical and contemporary demography of Nicaragua's Atlantic Coast. In: CIDCA (Ed.), Ethnic Groups and the Nation State. University of Stockholm, Stockholm, pp. 7-31.

Harborne, J.B. (1988) Phytochemical Methods: A Guide to Modern Techniques of Plant Analysis. Chapman and Hall, New York.

Hegnauer, R. (1962) Chemotaxonomie der Pflanzen. Band 1. Birkhäuser Verlag, Basel.

Hegnauer, R. (1963) Chemotaxonomie der Pflanzen. Band 2. Birkhäuser Verlag, Basel.

Hegnauer, R. (1964) Chemotaxonomie der Pflanzen. Band 3. Birkhäuser Verlag, Basel.

Hegnauer, R. (1966) Chemotaxonomie der Pflanzen. Band 4. Birkhäuser Verlag, Basel.

Hegnauer, R. (1969) Chemotaxonomie der Pflanzen. Band 5. Birkhäuser Verlag, Basel.

Hegnauer, R. (1973) Chemotaxonomie der Pflanzen. Band 6. Birkhäuser Verlag, Basel.

Hegnauer, R. (1986) Chemotaxonomie der Pflanzen. Band 7. Birkhäuser Verlag, Basel.

Hegnauer, R. (1989) Chemotaxonomie der Pflanzen. Band 8. Birkhäuser Verlag, Basel.

Hegnauer, R. (1990) Chemotaxonomie der Pflanzen. Band 9. Birkhäuser Verlag, Basel.

Hegnauer, R. (1992) Chemotaxonomie der Pflanzen. Band 10. Birkhäuser Verlag, Basel.

Hegnauer, R. (1994) Chemotaxonomie der Pflanzen. Band 11 a. Birkhäuser Verlag, Basel.

Hultin, E. and Torssell, K. (1965) Alkaloid screening of Swedish plants. Phytochemistry 4, 425-433.

IUCN (1986) 60000 plants under threat. Threatened Plants Newsletter 16, 2-3.

Johns, T. (1990) With Bitter Herbs They Shall Eat It. The University of Arizona Press, Tucson.

Karrer, W. (1958) Konstitution und Vorkommen der Organischen Pflanzenstoffe (exclusive Alkaloide). Band 12. Birkhäuser Verlag, Basel.

Karrer, W. (1977) Konstitution und Vorkommen der Organischen Pflanzenstoffe (exclusive Alkaloide). Band 17, Ergänzungsband 1. Birkhäuser Verlag, Basel.
Karrer, W. (1981) Konstitution und Vorkommen der Organischen Pflanzenstoffe (exclusive Alkaloide). Band 25, Ergänzungsband 2, Teil 2. Birkhäuser Verlag, Basel.

Karrer, W. (1985) Konstitution und Vorkommen der Organischen Pflanzenstoffe (exclusive Alkaloide). Band 28, Ergänzungsband 2, Teil 2. Birkhäuser Verlag, Basel.

Kiang, A.K., Douglas, B. and Morsingh, F. (1961) A phytochemical survey of Malaya. II. Alakaloids. Journal of Pharmacy and Pharmacology 13, 98-104.

Lawrence, G.H.M. (1951) Taxonomy of Vascular Plants. The Macmillan Publishing Co., New York.

Lucas, G.L. (1978) Conservation: recent developments in international cooperation. In: G.T. Prance and T.S. Elias (Eds.), Extinction is Forever: Threatened and Endangered Species of Plants in the Americas and Their Significance in Ecosystems Today and in the Future. New York Botanical Garden, New York, pp. 356-359.

Martinez, M. (1991) Catálogo de Nombres Vulgares y Cientificos de Plantas Mexicanas. Fondo de Cultura Económica, México.

Morton, J.F. (1981) Atlas of Medicinal Plants of Middle America, Vol. 1-2. Charles C. Thomas, Springficld, IL

Myers, N. (1984) The Primary Source: Tropical Forests and Our Future. W.W. Norton and Company, New York.

Myers, N. (1985) Conversion of Tropical Moist Forests. The Geographical Journal 151, 101-102.

Perry, L.M. (1980) Medicinal Plants of East and South East Asia. MIT Press, Cambridge, MA.

Principe, P.P. (1992) Valuing the biodiversity of medicinal plants. In: O. Akerele, V. Heywood and H. Synge (Eds.), Conservation of Medicinal Plants. Cambridge University Press, New York, pp. 79-124.

Raven, P.H. (1988) Our diminishing tropical forests. In: E.O. Wilson (Ed.), Biodiversity. National Academy Press, Washington, DC, pp. 119-122.

Schultes, R.E. (1986) Ethnopharmacological conservation: a key to progress in medicine. Opera Botanica 92, 217-224.

Smutko, G. (1985) La Mosquitia: Historia y Cultura de la Costa Atlántica. Editorial La Ocarina, Managua.

Soejarto, D.D. (1993) Logistics and politics in plant drug discovery: the other end of the spectrum. In: A.D. Kinghorn and M.F. Balandrin (Eds.), Human Medicinal Agents from Plants. American Chemical Society, Washington, DC, p. 97.

Soejarto, D.D., Gyllenhaal, C., Ashton, P.S. and Sohmer, S.H. (1996) Plant explorations in Asia under the sponsorship of the National Cancer Institute, 1986-1991: an overview. In: M.J. Balick, E. Elisabethsky and S.A. Laird (Eds.), Medicinal Resources of the Tropical Forest: Biodiversity and its Importance to Human Health. Columbia University Press, New York, p. 285.

Stahl, E. (1969) Thin-Layer Chromatography: a Laboratory Handbook. Springer-Verlag, Berlin.

Stermitz, F.R., Belovsky, G.N., Ng, D. and Singer, M.C. (1989) Quinolizidine alkaloids obtained by Pedicularis semibarbata (Scrophulariaceae) from Lupinus fulcratus (Leguminosae) fail to influence the specialist herbivore Euphydryas 
editha (Lepidoptera). Journal of Chemical Ecology 15, 2521-2530.

Sutton, S.Y. (1989) Nicaragua. In: D.G. Campbell and H.D. Hammond (Eds.), Floristic Inventory of Tropical Countries: the Status of Plant Systematics, Collections, and Vegetation, plus Recommendations for the Future. New York Botanical Garden, New York, pp. 299-304.

Tennekoon, K.H., Jeevathayaparan, S., Angunawala, P., Karunanayake, E.H. and Jayasinghe, K.S.A. (1994) Effect of Momordica charantia on key hepatic enzymes. Journal of Ethnopharmacology 44, 93-97.
Tyler, V.E., Brady, L.R. and Robbers, J.E. (1988) Pharmacognosy. Lea and Febiger, Philadelphia.

Willaman, J.J. and Schubert, B.G. (1961) Alkaloid-bearing plants and their contained alkaloids. U.S. Department of Agriculture, Technical Bulletin No.1234, Washington, DC.

Willaman, J.J. and Hui-Lin Li. (1970) Alkaloid-bearing plants and their contained alkaloids. Lloydia 33, 1-286.

Yang, S.L. and Walters, T.W. (1992) Ethnobotany and economic role of the Cucurbitaceae of China. Economic Botany 46, 349-367. 